\title{
АГААР МАНДЛЫН ТУНГАЛАГЖИЛТЫН КОЭФФИЦИЕНТЫГ ТООЦООЛОХ НЬ
}

\author{
Г.ДаваахҮҮ \\ ${ }^{1}$ ШУА-ийн Одон орон геофизикийн судалгааны төв, \\ цахим шуудан: davaahuи@rcag.ac.mn, batmunkh@rcag.ac.mn \\ ${ }^{2} О Х У$-ын ШУА-ийн Хавсарга математикийнхүрээлэн \\ ${ }^{3} О Х У$-ын ШУА-ийн Сансар судлальн хүрээлэн
}

\begin{abstract}
The ability of the atmosphere to pass electromagnetic wave depends on the mass of air, traced rays, as well as water vapor and dust in the air. Transparency of the atmosphere varies for different wavelengths of radiation and the greater the smaller the absorption and scattering in the atmosphere. Transparency of the atmosphere can be characterized by a transmission coefficient equal to the percentage of radiation that passes through the atmosphere at the steep fall-rays, or so-called turbidity factor, which shows the extent to which the transparency of the real atmosphere in these conditions is different from a perfectly clean and dry (perfect) air. The atmospheric transparency at various points of the globe is not the same. The most transparent air into the pole regions because there it contains the smallest amount of dust and moisture. Changes in humidity and dust content of air in this paragraph for the year determines the annual variation of atmospheric transparency at this point. In this paper we define the atmospheric transmission coefficient from measurements of solar UV radiation in different parts of Mongolia.
\end{abstract}

Keywords: atmospheric transparency, atmospheric transmission coefficient, solar UV radiation

\section{Оршил}

2000 оноос нарны хэт ягаан цацрагийн судалгааны ажлыг бусад орны түвшинтэй нийцүүлэх үүднээс цацрагийн эрчмийг Франц улсад үйлдвэрлэсэн VLX-3W багажаар хэмжих болсон. Ихэнх хэмжилтийг одон орныг судлах оргилд байгуулсан байнгын цэгт, түүнчлэн байгаль экологи, газарзүйн онцлог байдал, байршилын далайн түвшин, улиралын онцлог,агаар мандлын тунгалаг чанар зэрэгтэй уялдуулан Замын-Үүд, Сайншанд, Чойр, Эрдэнэт, Сэлэнгэ, Төв болон баруун, зүүн бүс нутгийн төв сууринг хамруулан явуулж, нөлөөлөх хүчин зүйлүүдийг тооцоолж байна [1-3]. (1-p зурагт нарны хэт ягаан цацраг хэмжих багажийг үзүүлэв)

\section{Нарны хэт ягаан цацрагийн хэмжилт}

Нарны хэт ягаан цацрагийн хэмжилтийн материалаас үзэхэд цацрагийн хамгийн их утга үд дунд буюу нар өндөрт хөөрч голдочоор гарах үед тохиож байгаа нь цацраг нэвтрэх агаар мандлын оптик зузаан хамгийн бага, шингээх чадвар харьцангуй буурсан үетэй давхцаж байна. Цацрагийн утга хэдийгээр тухайн газар нутгийн байгаль экологийн онцлог, агаар мандлын тунгалаг чанар зэрэг хүчин зүйлээс хамаардаг ч нарны өндрөөс шалтгаалах 
нь илүүтэй юм [1]. Тухайлбал, тухайн цэг дээрх нарны хэт ягаан цацрагийн 365нм, 312нм долгионы муж дахь эрчим хугацаанаас хамаарсан байдлыг авч үзье. (2-р зураг)

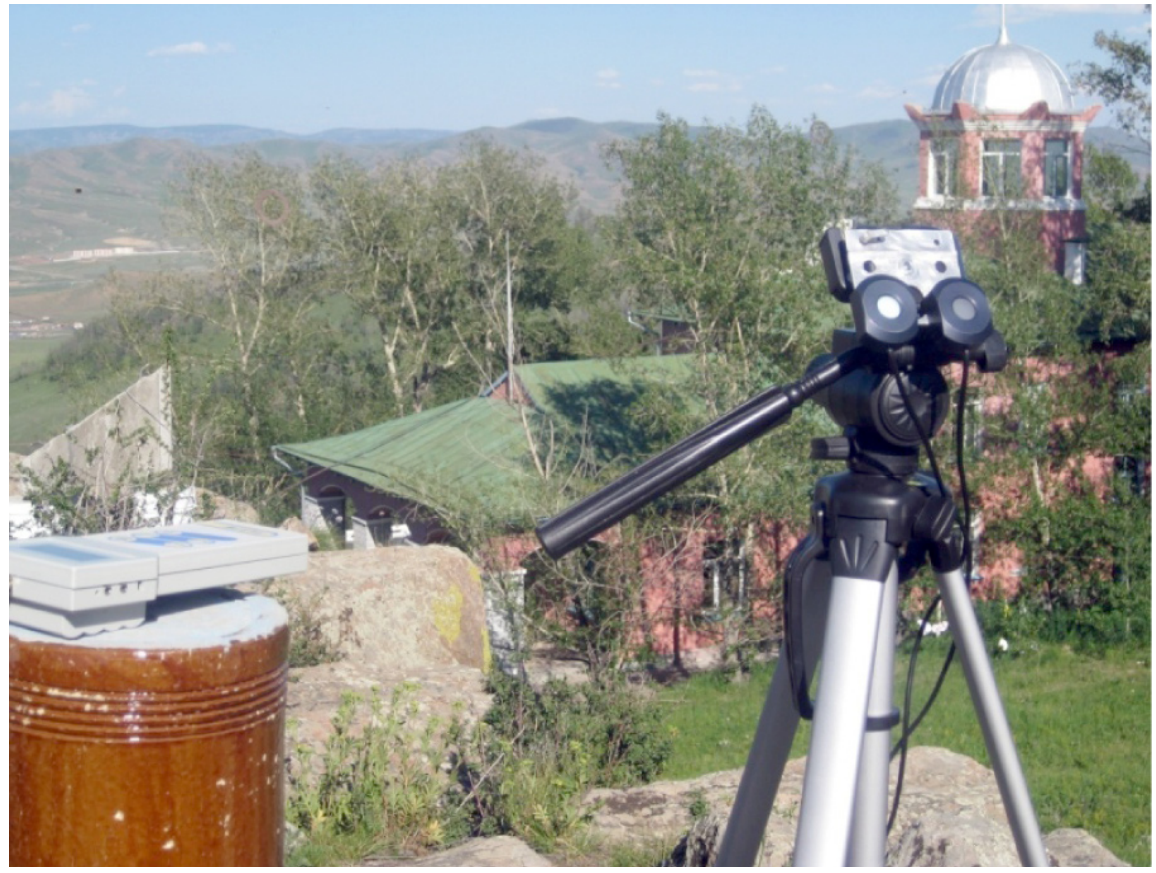

1-р зураг. Нарны хэт ягаан цачраг хэмжих $V L X-3 W$ багаж
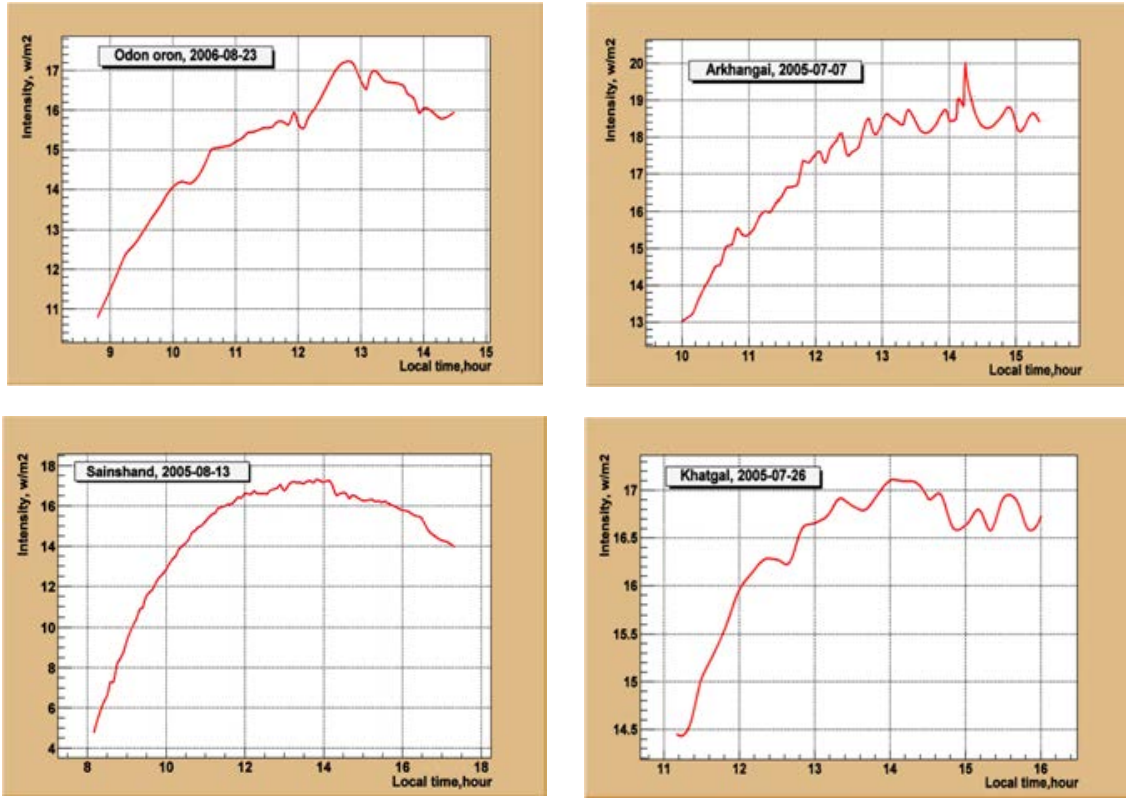

2-р зураг.Нарны хэт ягаан ичачрагийн харьцุангуй эрчим (долгионы урт 365 нм) янз бүрийн өргөрөг уртраг дээр (Улаанбаатар, Архангай, Сайншанд, Хатгал) 
Дээрх 2-р зургаас үзэхэд нарны хэт ягаан цацрагийн эрчмийн их утга нар өндөрт хөөрсөн үе буюу агаар мандлын оптик зузаан хамгийн бага болох агшинтай уялдахын зэрэгцээ ихэнх тохиолдолд агаарын турбулент урсгалын нөлөө мэдрэгдэж эрчим хэлбэлзэж байна. Харин нарны өндөр ижил байхад цацрагийн эрчим өөр өөр ажиглагдаж байгаа нь тухайн газар нутгийн агаар мандлын онцлог шинж чанар (агаарт дахь хийн агууламжийн өөрчлөлт), сарнисан цацраг зэрэг хүчин зүйлтэй холбоотой юм. Тухайлбал, цэлмэг өдөр хэмжсэн цацрагийн эрчим нарны ижил өндөрт Замын-Үүд, Сайншанд,Чойрт ялгаатай байна. Үүнийг цацрагийн эрчим нарны өндрийн хамаарлаас ажиглаж болно.
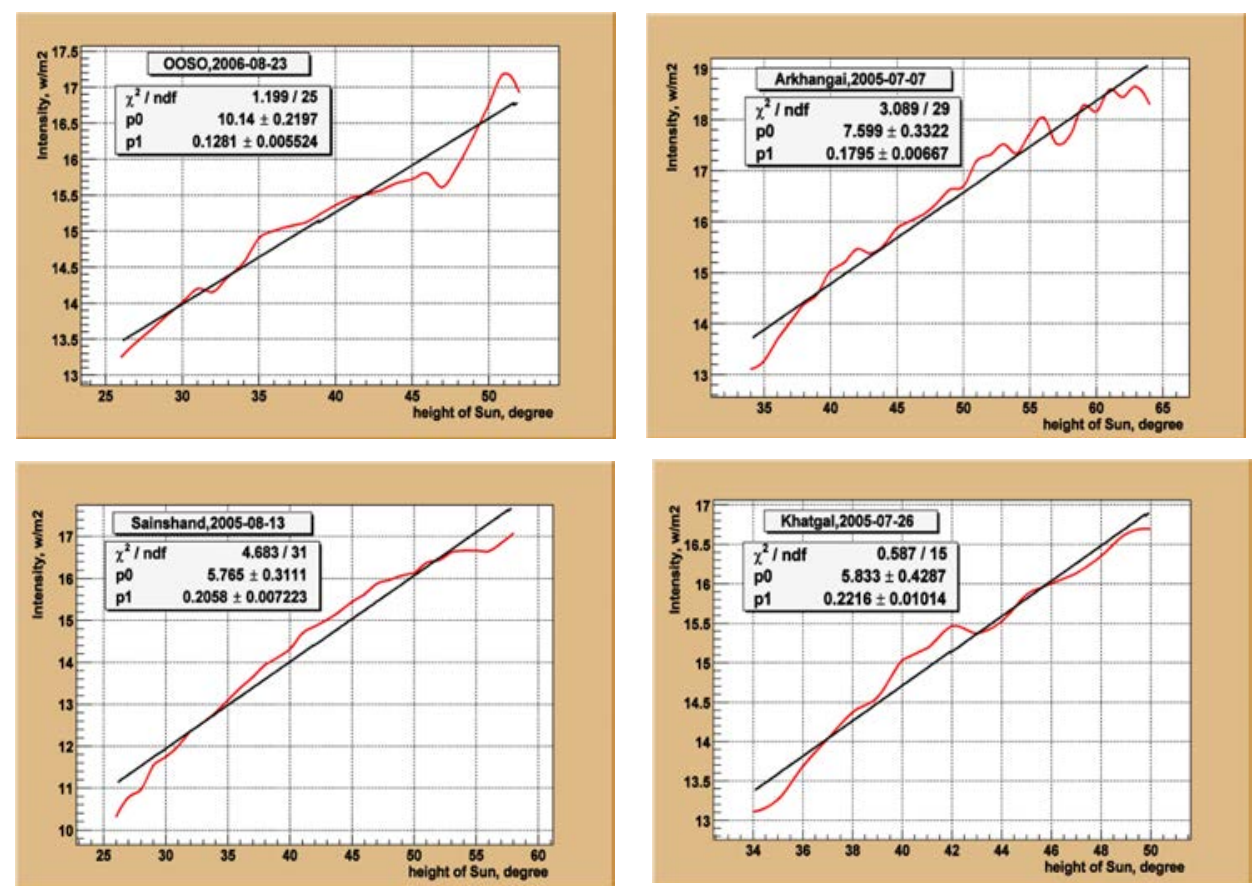

3-р зураг. Нарны хэт ягаан цамрагийн харьизангуй эрчим

(долгионы урт 365 нм) нарны өндрийн хамаарал

3-р зургаас ажиглахад нарны хэт ягаан цацрагийн эрчмийн гол өөрчлөлт нь агаар мандлын оптик зузаантай холбоотой байна.

Хэрэв агаар мандлын тунгалаг төлөв байдал нэгэн төрөл жигд бол нарны шулуун цацрагийн хэмжээ зөвхөн нарны өндрөөс хамаарна. Бидний цацрагийн хэмжилтэнд хэрэглэж байгаa багаж нийлбэр цацрагийг хэмжиж байгаа учраас тухайн орон нутгийн агаар мандлыг физик төлөв, газарзүйн байдал зэрэг хүчин зүйлийн нөлөөнөөс нарны хэт ягаан цацрагийн эрчим өөрчлөгдөж байна.

\section{Агаар мандлын тунгалагжилтын коэффициент тооцоолох нь}

Дэлхийн агаар мандлын оптик зузаан долгионы уртаас хамаарч өөр өөр бүртгэгддэг. Тухайлбал, үзэгдэх мужид нимгэн байхад хэт ягаан цацрагийн хувьд зузаан бөгөөд оптик зузаан нь тунгалагжилтын коэффициенттой шууд холбоотой байдаг. Тунгалагжилтын 
коэффициентыг тодорхойлохдоо нийлбэр цацрагаас шулуун цацрагийг ялгах аргаар тодорхойлж болно [2,4].

Хэвтээ гадаргууд $\theta$ - өнцгөөр налсан хавтгайд тусах нарны нийлбэр цацрагийн хувьд дараах томъёог бичвэл:

$$
S_{N T}=S_{W D} \cdot \cos t+\frac{1}{2}(1+\cos \theta) S_{S}+\frac{1}{2} \rho_{1} 1-\cos \theta \cdot S_{H T}
$$

$S_{N T}$ - налуу гадаргад тусах нарны нийлбэр цацраг буюу бидний хэмжилт, $S_{N D}$ - перпендикуляр гадаргад тусах шууд цацраг, $S_{S}$ - сарнимал цацраг, $S_{H T}$ - хэвтээ гадаргад тусах нийлбэр цацраг, $p$ - ойсон цацраг $S_{H T}$ - (альбедо), $i$ - нарны чиглэл, уг гадаргад татсан нормаль хоёрын хоорондох өнцөг. Уг гадаргуу нарыг дагах системээр хөдлөх тохиолдолд (1) томъёо дараах хэлбэрт орно.

$$
\left.S_{N T}=S_{N D}+\frac{1}{2}(1+x) S_{S}+\frac{1}{2} \rho 1-x\right\rangle S_{H T}
$$

(1) томъёоноос хэвтээ гадаргууд тусах цацрагийн хувьд

$$
S_{N T}=S_{N D} \cdot x+S_{S}
$$

томъёог бичиж болно. Энд $x=\sinh$ ба $h$ - нь нарны өндөр

Сарнимал цацраг $S_{S}$ цаг уурын нөхцөл, үүлшилт, тоосжилтоос хамааран өргөн хязгаар дотор өөрчлөгддөг. Тэнгэр цэлмэг байх тохиолдолд релейн сарнил зонхилж байна гэж үзвэл сарнимал цацрагийг Берляжегийн тэгшитгэлээр тооцоолж болно.

$$
S_{s}=\frac{S_{0} \cdot x(1-R)}{2(1-1.4 x \cdot \operatorname{LnR})}
$$

Энд

$$
R=\frac{S_{W D}}{S_{0}}
$$

$S_{O}$ - хэт ягаан цацрагийн муж дахь нарны тогтмол

$R$ - бол агаар мандлын нэвтрүүлэх чадвар бөгөөд тунгалагжилтын коэффициенттэй дараахь томъёогоор холбогдоно.

$$
P_{k}=R^{x}
$$

(2), (3) ба (4) томъёонуудаас $R$-ийн дараах хялбар томъёонд хүрнэ.

$$
R=\frac{R^{\prime}-x_{3}}{x_{1}-x_{3}}
$$


Энд $R^{x}=S_{N T} / S_{\text {n }}$

$$
\left.\begin{array}{c}
x_{1}=1+\frac{1}{2} x(1-x) \rho \\
x_{2}=\frac{1}{2\left(1+x+\rho_{1} 1-x\right)} \\
x_{3}=\frac{1}{2} x \cdot x_{2} \frac{1}{1-1.4 x-\ln R}
\end{array}\right\}
$$

(6) -ийг бодож дараа нь тунгалагжилтын коэффициент $P_{k}$-ийг тухайн хугацаа буюу нарны өндөр (5) томъёогоор олж тооцоолсон олон тооны $P_{k}$-ийн хувьд хамгийн бага квадратын аргаар дундаж шулууныг байгуулж, эцэст нь зенит (эгц оройд) дахь утгыг гаргана. Энэ бол бидний авч үзэж байгаа агаар мандлын тунгалагжилтын коеффициент юм. 1-p хүснэгтэнд нарны хэт ягаан цацраг хэмжигчээр хэмжиж тодорхойлсон зарим цэгүүдэд тодорхойлсон тунгалагжилтын коэффициентыг үзүүлэв.

\begin{tabular}{l|c} 
1-p хүснэтт. 365 нм долгионы мужид тодорхойлсон агаар мандлын тунгалагжилтын коэффищие \\
\hline \multicolumn{1}{c|}{ Цэгийн нэр } & Коэффициент P \\
\hline Улаанбаатар & 0.4173 \\
Хатгал & 0.3955 \\
Сайншанд & 0.3834 \\
Архангай & 0.4611 \\
Дархан & 0.3962 \\
Мөрөн & 0.4021 \\
Эрдэнэт & 0.3800 \\
Завхан & 0.3916 \\
Увс & 0.3541 \\
Баян-Өлгий & 0.4147 \\
Дундаж утга & 0.3996 \\
\hline
\end{tabular}

Бидний тооцоолсон энэхүу коэффициент нь тухайн газар нутгийн онцлог болон улиралын байдлаас хамааран хэлбэлзэж байгаа боловч 365 нм долгионы муж орчимд 0.4 утга хадгалагдаж байна.

\section{Дүгнэлт}

1. Нарны хэт ягаан цацрагийн эрчмийн их утга нар өндөрт хөөрсөн үе буюу голдочоор өнгөрөх агшинд агаар мандлын оптик зузаан хамгийн бага байгаатай уялдаж байна.

2. Агаар мандлын тунгалагжилтын коэффициент нь тухайн орон нутгийн агаарын физик төлөв, газарзүйн онцлог болон улирлаас хамааран өөрчлөгдөж байгаа ч 365 нм долгионы муж орчим ойролцоо утга хадгалагдаж байна. 


\section{Ном зүй}

1. Ц ЦовоохүҮ Ч., Батмөнх Д., Даваахүу Г. Ультрафиолетовый климат Монголии. Одон орон Геофизик судлал, №2, УБ, 2003, сc. 63-65.

2. Д.Батмунх Д., Лхагважав Ч., Даваахуу Г., Цовоохуу Ч. Ультрафиолетовое излучение и прозрачность атмосферы в Монголии. Современная геодинамика и опасные природные процессы в центральной Азии. Иркутск, 2006, сс.206-214.

3. Davaakhuu G., Batmunkh D., Lkhagavajav Ch., Bayarmaa J. Impacts of the Solar UVradiations. Proceedings of The 2-nd International Conference "X-ray Analysis", NUM, Ulaanbaatar, Mongolia, 23-26 September, 2009,pp.224-227

4. www.epa.gov/sunwise/uvcalc.html 